\title{
GRADE KOMPOSISI VITAMIN A ASI PADA PENYIMPANAN MICROKONTROLER ARDUINO NANO DENGAN PENYIMPANAN PADA LEMARI PENDINGIN DAN SUHU RUANGAN
}

\section{Comparison Between the Grade of Vitamin A in Breast Milk Stored in Arduino Nano Microcontroller Storage and the One Stored in Refrigerator and Room Temperature}

\author{
Nuraiman $^{1 *}$, Mardiana Ahmad ${ }^{2}$, Suryani Asad ${ }^{3}$ \\ ${ }^{1}$ Akademi Kebidanan Graha Ananda \\ ${ }^{2}$ Program Studi Ilmu Kebidanan Unversitas Hasanuddin \\ ${ }^{3}$ Fakultas Kedokteran Gizi Universitas Hasanuddin \\ *Email korespondensi: anandaaiman45@gmail.com
}

\begin{abstract}
ABSTRAK
Penelitan ini bertujuan membandingkan komposisi Vitamin A pada ASI yang disimpan menggunakan Mikrocontroller Arduino Nano, dengan Lemari Pendingin dan Suhu Ruangan. Penelitian ini berjenis percobaan murni. Teknik penyampelan yang digunakan adalah penyampelan purposive dan diperoleh sebanyak 45 sampel. Kadar komposisi Vitamin A ASI diuji dengan Spektrofotometrik UVVis, Perlakuan dilakukan dengan memompa menggunakan pompa doubell pumping kemudian disimpan menggunakan Mikrocontroller Arduino Nano, Lemari Pendingin dan Suhu Ruangan selama 8 jam, Analisa data menggunakan uji One-Way Anova. Hasil penelitian menunjukan bahwa komposisi Vitamin A ASI yang disimpan menggunakan penyimpanan Mikrocontroller Arduino Nano pada suhu 300C lebih tinggi dibanding ASI yang disimpan pada Lemari pendingin pada suhu 40C dan pada Suhu Ruangan $(\mathrm{p}=0,064)$. Vitamin A lebih baik disimpan menggunakan Mikrocontroller Arduino Nano.
\end{abstract}

Kata Kunci: Vitamin A; ASI; Mikrocontroller Arduino Nano; Lemari Pendingin; Suhu Ruangan

\section{ABSTRACT}

The study aims to compare the composition of Vitamin A in breast milk stored in Arduino Nano Microcontroller and the one stored in refrigator and room temperature. This research was a pure experiment type. The sample was determined using purposive sampling technique consisting of 45 samples. The composition level of Vitamin A in breast milk was tested using UV-Vis Spectrophotometry. The treatment was done by pumping using double pumping pump and then it was stored using Arduino Nano Microcontroller, refrigerator, and room temperature for 8 hours. The data were analysed using One-Way Anova test. The results of the research indicate that the composition of Vitamin A in breast milk stored using Arduino Nano Microcontroller at a temperature of $30^{\circ} \mathrm{C}$ is hinger than the one stored in refrigerator at a temperature of $4^{\circ} \mathrm{C}$ and at a room temperature $(p=0,064)$. Thus, Vitamin $A$ is better stored in Arduino Nano Microcontroller

Keywords: Vitamin A; Breast milk; Arduino Nano Microcontroller; Refrigerator; Room Temperature https://doi.org/10.33860/jik.v14i2.172

(C) 2020 by the authors. Submitted for possible open access publication under the terms and conditions of the Creative Commons Attribution (CC BY SA) license (https://creativecommons.org/licenses/by-sa/4.0/).

\section{PENDAHULUAN}

Air Susu Ibu (ASI) adalah makanan tepat yang mengandung banyak sifat antioksidan, antibakteri, prebiotik, probiotik, dan kekebalan tubuh selain protein, lemak esensial, enzim, hormon, dan sebagainya. ${ }^{(1,2)}$ Pemberian ASI ekslusif selama 6 bulan dan berlanjut sampai 2 tahun pertama kehidupan dapat mencegah $13 \%$ dari 10 juta kematian setiap tahun untuk anakanak dibawah 5 tahun. $^{(3,4)}$ World Health Organization (WHO) mencatat rata-rata pemberian ASI Eksklusif di dunia baru berkisar $36 \%$. Cakupan ASI eksklusif hanya 24\% Indonesia menempati peringkat ketiga dari 51 Negara yang mengikuti penilaian status 
kebijakan dan program yang dilakukan oleh International Baby Food Action Network (IBFAN). Pemberian ASI sangat penting dikarenakan dapat bermanfaat bagi bayi dan ibunya. Bagi bayi, ASI adalah makanan dengan kandungan gizi yang paling berguna untuk kebutuhan bayi, melindungi dari berbagai infeksi dan memberikan hubungan kasih sayang yang mendukung semua aspek perkembangan bayi termasuk kesehatan dan kecerdasan bayi..$^{(5-8)}$ American Academy of Pediatrics saat ini merekomendasikan agar Air Susu Ibu yang tidak terpakai disimpan dalam waktu 24 jam sehingga dapat dicairkan dan digunakan kembali, jika disimpan dengan tepat boleh dapat digunakan 3-6 bulan jika dipertahankan pada suhu $-20^{\circ} \mathrm{C} .^{(9-10)}$ Bahan pangan nabati yang relatif lebih tahan lama waktu penyimpanannya dibandingkan dengan penyimpanan ASI yang merupakan produk non-nabati harus memerlukan kondisi yang lebih optimal dengan penggunaan metode yang paling sesuai dari berbagai macam penyimpanan yang ada. ${ }^{(11)}$

Sumber vitamin A pada ASI terbaik bagi bayi. Kekurangan Vitamin A diderita oleh 250 juta bayi diseluruh dunia. Vitamin A sangat penting untuk mempertahankan kesehatan dan pencegahan penyakit. Tanpa ASI, bayi baru lahir memiliki cadangan Vitamin A hanya untuk beberapa minggu saja. Sehingga Vitamin A yang cukup selama 6 bulan sangat dibutuhkan oleh bayi. Beberapa penelitian menunjukkan bahwa terdapat perbedaan komposisi ASI yang disimpan dalam wadah penyimpanan, namun hingga saat ini belum ditemukan penelitian yang membahas secara signifikan mengenai komposisisi mikronutrien ASI. ${ }^{(10,13,14)}$ Maka pada penelitian ini peneliti ingin mengetahui apakah ada perbedaan komposisi Vitamin A pada ASI yang disimpan di dalam penyimpanan microkontroller arduino nano, lemari pendingin dan suhu ruangan. Penelitian ini bertujuan untuk membandingkan komposisi Vitamin A ASI yang disimpan menggunakan Microcontroller Arduino Nano, Lemari Pendingin dan Suhu Ruangan.

\section{METODE PENELITIAN}

Penelitian ini dilakukan di wilayah kerja Puskesmas Jumpandang Baru Kota Makassar. Bulan November 2018 hingga Januari 2019. Jenis penelitian observational dengan desain kuasi eksperimen.Populasi adalah seluruh ibu menyusui yang ada di wilayah kerja Puskesmas Jumpandang Baru Kota Makassar. Sampel sebanyak 15 orang secara purposive sampling yang telah memenuhi kriteria inklusi yaitu ibu bekerja, multipara, usia 24-35 tahun, Postpartum hari ke $\geq 14$, ibu yang sehat dan bersedia untuk mengikuti penelitian ini dengan menandatangani informed consent yang telah dikeluarkan oleh Komite Etik Fakultas Kedokteran Universitas Hasanuddin Makassar. Pengumpulan data diperoleh secara langsung dari responden yang dikumpulkan melalui lembar persetujuan penelitian. Selain itu pengambilan sampel ASI secara langsung berupa sampel ASI sebanyak $30 \mathrm{ml}$ dan dibagi menjadi 3 tempat jenis penyimpanan yaitu $10 \mathrm{ml}$ pada penyimpanan Microcontroller Arduino Nano dengan suhu $30^{\circ} \mathrm{C}$ selama 8 jam, $10 \mathrm{ml}$ pada lemari pendingin dengan suhu $4^{0} \mathrm{C}$ selama 8 jam dan $10 \mathrm{ml}$ pada suhu ruangan selama 8 jam. Selanjutnya ASI diperiksa di Balai Besar Laboratorium Kesehatan Makassar. Data yang diperoleh dianalisis menggunakan program statistik dalam komputer yaitu menggunakan SPSS 24 dengan tingkat kepercayaan $95 \%$. Uji statistic yang akan digunakan peneliti adalah uji One-Way Anova. Kemudian untuk melihat perbedaan kadar komposisi Vitamin A yang disimpan kedalam penyimpanan Microcontroller Arduino Nano, lemari pendingin dan suhu ruangan.

\section{HASIL}

Karakteristik responden berdasarkan umur tertinggi yaitu ibu yang berumur 25-35 tahun dan tidak berisiko sebanyak 13 orang (70\%), sedangkan untuk karakteristik responden berdasarkan jenis pekerjaan peneliti menentukan jumlah dan jenis pekerjaan yang dijadikan sebagai sampel dengan memprioritaskan ibu yang bekerja diluar rumah, masing-masing diperoleh yaitu 5 orang $(33,3 \%)$. masa laktasi terbanyak pada penelitian ini yaitu pada umur 3 bulan sebanyak 9 orang $(60 \%)$, untuk status gizi semua sampel memiliki status gizi yang normal dan status gizi lebih, tidak ada sampel yang berstatus gizi kurang dan jumlah sampel terbanyak berdasarkan status gizi yaitu ibu yang berstatus gizi normal sebanyak 12 orang (80\%). 
Tabel 1. Karakteristik Responden menurut Umur dan Jenis Pekerjaan

\begin{tabular}{|c|c|c|}
\hline Karakteristik Responden & $\mathbf{F}$ & $(\%)$ \\
\hline \multicolumn{3}{|l|}{ Umur Ibu } \\
\hline Berisiko $(<25->35)$ & 2 & 30,0 \\
\hline Tidak berisiko (25-35) & 13 & 70,0 \\
\hline \multicolumn{3}{|l|}{ Jenis Pekerjaan } \\
\hline PNS & 5 & 33,3 \\
\hline Buruh & 5 & 33,3 \\
\hline Pedagang & 5 & 33,3 \\
\hline Jumlah & 15 & 100 \\
\hline
\end{tabular}

Sumber: Data Primer, 2019

Tabel 2. Masa Laktasi dan Status Gizi Responden

\begin{tabular}{lll}
\hline Masa Laktasi dan Status Gizi & F & $(\boldsymbol{\%})$ \\
\hline Masa Laktasi & & \\
3 bulan & 9 & 60.0 \\
4 bulan & 4 & 26.7 \\
5 bulan & 2 & 13.3
\end{tabular}

\begin{tabular}{lcc}
\hline Masa Laktasi dan Status Gizi & F & $\mathbf{( \% )}$ \\
\hline Status Gizi & & \\
Overweight & 3 & 20 \\
Normal & 12 & 80 \\
Underweight & 0 & 0 \\
\hline Total & 15 & 100 \\
\hline Sumber: Data Primer 2019 & &
\end{tabular}

Sumber: Data Primer, 2019

Rata-rata kadar komposisi Vitamin A tertinggi adalah ASI yang disimpan pada penyimpanan mikrokontroler arduino nano pada suhu $30^{\circ} \mathrm{C}$ sebesar $0,38 \%$. Nilai signifikan yang diperoleh yaitu nilai $\mathrm{p}=0,064$, sehingga dapat disimpulkan bahwa tidak terdapat perbedaan yang signifikan terhadap masingmasing penyimpanan ASI terhadap rata-rata kadar komposisi Vitamin A pada ASI.

Tabel 3 Signifikansi Perbandingan Rata-Rata Kadar Komposisi Vitamin A ASI Pada Penyimpanan Mikrokontroler Arduino Nano Pada Suhu 30º, Suhu Ruangan dan Lemari Pendingin Pada Suhu $4^{0} \mathrm{C}$.

\begin{tabular}{lcccc}
\hline \multirow{2}{*}{ Jenis penyimpanan } & Lama & \multicolumn{2}{c}{ Nilai Vitamin A ASI $(\boldsymbol{\mu g} / \mathbf{m l})$} & \multirow{2}{*}{ p-value } \\
\cline { 3 - 4 } & Penyimpanan & Rerata & IK 95\% & \multirow{2}{*}{0,064} \\
Lemari pendingin suhu 40c & 8 Jam & 0,30 & $0,24-0,37$ & \multirow{2}{*}{ Suhu ruangan } \\
Mikrokontroler AN suhu 300c & 8 Jam & 0,31 & $0,26-0,37$ & $0,36-0,43$ \\
\hline
\end{tabular}

Sumber: Data Primer, 2019

\section{PEMBAHASAN}

Jenis penyimpanan dan lama penyimpanan pada sampel yang diamati dalam penelitian ini yakni; suhu ruangan (selama 8 jam), lemari pendingin (selama 8 jam) dan Mikrokontroller Arduino Nano (selama 8 jam). Pada tabel .3 memperlihatkan bahwa secara statistik nilai yang diperoleh yaitu nilai $\mathrm{p}=0,064$ sehingga tidak terdapat perbedaan yang signifikan terhadap masing-masing penyimpanan ASI pada komposisi vitamin A yang terdapat pada ASI.

Dengan berbagai kandungan yang ada didalam ASI mengakibatkan ASI menjadi sangat senstif terhadap perubahan suhu. Penggunaan suhu yang rendah akan memberikan efek ASI bertahan lama. Sedangkan penggunaan suhu yang terlalu tinggi akan mematikan bakteri-bakteri pathogen yang terkandung didalam ASI, namun merusak kandungan lemak dan protein. ${ }^{(14-16)}$

ASI merupakan sumber mikronutrien yang baik. Kandungan mikronutrien dalam ASI membantu fungsi fisiologis pada bayi atau balita. Pada kondisi ibu yang sehat, ASI merupakan sumber vitamin A yang baik untuk bayi dan balita. ${ }^{(17)}$ Kandungan Vitamin A didalam ASI tiap ibu berbeda-beda. Kadar Vitamin A pada ibu dengan status gizi baik pada kolostrum adalah sebesar $151 \mu \mathrm{g} / 100 \mathrm{ml}$, ASI transisional $88 \mu \mathrm{g} / 100 \mathrm{ml}$, sedangkan pada ASI mature sebesar $75 \mu \mathrm{g} / 100 \mathrm{ml}$ Vitamin A, Selain itu, asupan dan status Vitamin A selama kehamilan berpengaruh terhadap kandungan ASI.

Status Vitamin A pada bayi umumnya rendah karena secara fisiologi kemampuan transfer Vitamin A dari ibu kejanin sangat kecil, sehingga cadangan Vitamin A pada bayi hanya mencukupi kebutuhan bayi selama kurang dari 2 minggu. ${ }^{(18,19)}$ Suatu penelitian yang dilakukan di Pakistan pada tahun 2011 membuktikan bahwa pemberian suplemen Vitamin A pada anak usia 5-59 bulan di Negara tersebut mampu menekan angka kematian sampai $20 \%$ dan menunjukkan adanya pengurangan balita yang menderita penyakit akibat infeksi, diare, campak maupun kebutaan. Dari penelitian tersebut terlihat bahwa pentingnya Vitamin A tidak hanya sebatas pada pencegahan kebutaan, namun yang lebih 
penting lagi adalah kaitannya dengan kelangsungan hidup, pertumbuhan dan perkembangan serta kesehatan.

Mekanisme kerja Vitamin A dalam tubuh adalah vitamin yang larut dalam lemak di dalam tubuh juga dapat disimpan untuk jangka waktu yang lama. Pada umumnya Vitamin A ini disimpan dalam hati, setelah itu akan bisa bertahan lama sebelum nantinya akan diproses kembali oleh liver. ${ }^{(20)}$

\section{KESIMPULAN DAN SARAN}

Kami menyimpulkan bahwa komposisi Vitamin A dalam ASI yang disimpan pada Mikrokontroller Ardunino Nano lebih baik dibandingkan ASI yang disimpan pada suhu ruangan dan lemari pendingin, bagi ibu-ibu yang bekerja disarankan untuk bisa menggunakan dari masing-masing ketiga jenis penyimpanan tersebut, sehingga ASI Esklusif berhasil bagi ibu-ibu yang tidak bisa menyusui secara langsung.

\section{DAFTAR PUSTAKA}

1. Reyes-Foster BM, Carter SK, Hinojosa MS. Human Milk Handling and Storage Practices Among Peer Milk-Sharing Mothers. J Hum Lact. 2017;33(1):173-80.

2. Melnik BC, John SM, Schmitz G. Milk is not just food but most likely a genetic transfection system activating mTORC1 signaling for postnatal growth. Vol. 12, Nutrition Journal. 2013.

3. Andreas NJ, Kampmann B, Mehring Le-Doare K. Human breast milk: A review on its composition and bioactivity. Vol. 91, Early Human Development. 2015. p. 629-35.

4. Ewaschuk JB, Unger S, O'Connor DL, Stone D, Harvey S, Clandinin MT, et al. Effect of pasteurization on selected immune components of donated human breast milk. J Perinatol. 2011;31(9):593-8.

5. Ballard O, Morrow AL. Human Milk Composition. Nutrients and Bioactive Factors. Vol. 60, Pediatric Clinics of North America. 2013. p. 49-74.

6. Ezaki S, Ito T, Suzuki K, Tamura M. Association between Total Antioxidant Capacity in Breast Milk and Postnatal Age in Days in Premature Infants. J Clin Biochem Nutr. 2008;42(2):133-7.

7. Palmeira P, Carneiro-Sampaio M. Immunology of breast milk. Rev Assoc Med Bras. 2016;62(6):584-93.

8. Zonneveld MI, Brisson AR, van Herwijnen
MJC, Tan S, van de Lest CHA, Redegeld FA, et al. Recovery of extracellular vesicles from human breast milk is influenced by sample collection and vesicle isolation procedures. $\mathrm{J}$ Extracell Vesicles. 2014;3(1).

9. Ahrabi AF, Handa D, Codipilly CN, Shah S, Williams JE, McGuire MA, et al. Effects of Extended Freezer Storage on the Integrity of Human Milk. J Pediatr. 2016;177:140-3.

10. Akdag A, Nur Sari F, Dizdar EA, Uras N, Isikoglu S, Erel O, et al. Storage at -80??C Preserves the Antioxidant Capacity of Preterm Human Milk. J Clin Lab Anal. 2014;28(5):4158.

11. Substitusi P, Terigu T, Tepung D. Indonesian Journal of Human Nutrition. 2014;1(2):114-27.

12. Chang YC, Chen $\mathrm{CH}$, Lin MC. The macronutrients in human milk change after storage in various containers. Pediatr Neonatol. 2012;53(3):205-9.

13. Aksu T, Atalay Y, Türkyılmaz C, Gülbahar Ö, Hirfanoğlu IM, Demirel N, et al. The effects of breast milk storage and freezing procedure on interleukine-10 levels and total antioxidant activity. J Matern Neonatal Med. 2015;28(15):1799-802.

14. Bransburg-Zabary S, Virozub A, Mimouni FB. Human milk warming temperatures using a simulation of currently available storage and warming methods. PLoS One. 2015;10(6).

15. Delgado FJ, Contador R, Álvarez-Barrientos A, Cava R, Delgado-Adámez J, Ramírez R. Effect of high pressure thermal processing on some essential nutrients and immunological components present in breast milk. Innov Food Sci Emerg Technol. 2013;19:50-6.

16. Evans TJ, Ryley HC, Neale LM, Dodge J a, Lewarne VM. Effect of storage and heat on antimicrobial proteins in human milk. Arch Dis Child. 1978;53(3):239-41.

17. Mello-Neto J, Rondó PHC, Oshiiwa M, Morgano MA, Zacari CZ, Domingues S. The influence of maternal factors on the concentration of vitamin A in mature breast milk. Clin Nutr. 2009;28(2):178-81.

18. Dror DK, Allen LH. Retinol-to-fat ratio and retinol concentration in humanmilk show similar time trends and associations with maternal factors at the population level: A systematic review and meta-analysis. Adv Nutr. 2018;9:332S-346S.

19. Schweigert FJ, Frey SK, Mothes R, Dary O, Juarez P, Lascano V. A new test kit's potential for the rapid analysis of vitamin A in human and cow milk. Sight Life Mag. 2011;25(3):18-22.

20. Bates CJ. Vitamin A in pregnancy and lactation. Proc Nutr Soc. 2005;42(01):65-79. 